\title{
Correlation of Online Learning Evaluation With Students' Learning Outcomes in the Covid 19 Pandemic
}

\author{
H Hermansyah* \\ Physics Education Study Program \\ Universitas Samawa \\ Sumbawa Besar, Indonesia \\ hermansyah.fis92@gmail.com
}

\author{
Dwi Mardhia \\ Management of Aquatic Resources \\ Study Program \\ Universitas Samawa \\ Sumbawa Besar, Indonesia \\ dwimardhia@gmail.com
}

\author{
Fahmi Yahya \\ Physics Education Study Program \\ Universitas Samawa \\ Sumbawa Besar, Indonesia \\ fyahyaadam@gmail.com
}

\begin{abstract}
The Covid-19 outbreak greatly impacted the learning process at Universitas Samawa as one of higher education in Indonesia. This causes the learning process to be changed from face-to-face to online, including the learning evaluation process. This quantitative descriptive study aims to determine the correlation between the evaluation of online learning and student learning outcomes at Universitas Samawa. This research was conducted at Universitas Samawa with a number of respondents as many as 87 students who were selected using purposive sampling technique. The instrument used was a questionnaire with a Likert scale of 1 to 4 . The questionnaire contained statements about the correlation of the online learning evaluation process with student learning outcomes. The results of this study indicate that there is a positive correlation between the use of online learning evaluations and the learning outcomes of students at Universitas Samawa. The learning evaluation process is one of the external factors that have a contribution in influencing and determining student learning outcomes. Online learning evaluation could be the best solution that can be applied during the Covid-19 pandemic.
\end{abstract}

\section{Keywords—online learning evaluation, learning outcomes}

\section{INTRODUCTION}

The Covid-19 pandemic in Indonesia has been going on from early 2020 to the present. This pandemic has a significant impact on several important sectors such as the economy and education. This is in line with the statements made by Purwanto, et al [1] that the spread of the corona virus initially had a major impact on the economic and social world, but now the impact is also being felt by the world of education. The teaching and learning process in every school including at the higher education level is one part of the education sector that has been affected by the Covid-19 pandemic. UNESCO estimates that nearly 900 million students have been affected by the closure of educational institutions due to the Covid-19 pandemic [2].

The learning process which was originally carried out face-to-face, has turned into learning that is carried out online to follow the health protocol by applying an interaction pattern commonly known as social distancing or physical distancing. Every learning process is carried out online, and the learning evaluation stage is no exception

Learning evaluation is one of the important stages that must be carried out in a teaching and learning process to determine the level of achievement of learning objectives. Learning evaluation is carried out systematically with the main activities, namely measurement and assessment. Evaluation can provide an overview of the level of student mastery of the material, provide an overview of learning difficulties, and provide an overview of their respective positions [3]. Evaluation is the process of determining a program, namely whether a program is planned perfectly, well executed, achieved perfectly, and has a very broad impact [4]. The teaching and learning process at each stage, including the evaluation of learning, must still be carried out during a pandemic like this, this is because learning evaluation is an important part that must be carried out.

The learning evaluation stage is very important because it can be a benchmark for whether learning objectives are achieved or not as seen from the acquisition of student learning outcomes. Student learning outcomes are one of the benchmarks for whether the teaching and learning process and evaluation have gone well or not. If the learning outcomes have been obtained, then actions can be taken to improve or enhance the learning process through evaluation results for the better. A learning evaluation process should be improved after obtaining the results of the analysis that has been carried out through the information received. Bennett [5]; Pellegrino et al. [6] stated that evaluation does not only refer to collecting data systematically and analyzing information about students but also being able to interpret and act on information about their understanding and / or performance in relation to the achievement of learning objectives.

The current evaluation of learning is not carried out as usual such as face-to-face. This is because each higher education unit carries out teaching and learning activities online. This activity is carried out using the home learning method, where students and lecturers remain at home. The 
implementation of this activity is carried out using several platforms such as WhatsApp, Zoom, Google Classroom, and Schoology. Online learning evaluation is the most appropriate alternative solution during a pandemic so that lecturers can always get information about student learning outcomes and also it is considered easier and more efficient to obtain data on the level of students' understanding of the material that has been described.

\section{METHOD}

This type of research was a descriptive study with quantitative techniques. The subjects of this study were students from several study programs at the Universitas Samawa, Sumbawa Region, West Nusa Tenggara. The research sample was 75 students with different levels and were selected using purposive sampling technique. The research instrument used a Likert scale questionnaire with a scale of 14 , where a scale of 1 indicates disagree, 2 indicates disagreement, 3 indicates agree, and 4 indicates strongly agree. The questionnaire used contains several statements relating to the platform used at the time of the evaluation, the level of accuracy of the online evaluation in measuring student learning outcomes bills, and providing special forms for students to comment on the evaluation process.

Students' learning outcomes data are obtained from the results of the final semester examinations by several lecturers who teach subjects related to the selected respondents. The data analysis technique was carried out by classifying the data, tabulating the data, scoring the respondents 'answers, processing the number of respondents' answers, calculating the percentage of questionnaire answers for each statement item, calculating the average percentage of the questionnaire, visualizing the data in the form of images, and interpreting the percentage of questionnaire answers as a whole. The correlation between online learning evaluation and learning outcomes can be determined by analyzing data using SPSS. The data obtained in qualitative form are then quantified using the following equation:

$$
\text { value obtained: } \mathrm{N}=\frac{\text { the number of scores obtained }}{\text { the maximum number of scores }} \times 10
$$

TABLE I. INTERPRETATION CRITERIA FOR QUESTIONNAIRE SCORES

\begin{tabular}{|l|l|}
\hline Scale & Category \\
\hline 100 & Strongly Agree \\
\hline $75-99$ & Agree \\
\hline $50-74$ & Disagree less \\
\hline $0-49$ & Disagree \\
\hline
\end{tabular}

\section{RESULTS AND DISCUSSION}

Online learning evaluation data collection using a questionnaire with the help of google form has been carried out. In the questionnaire, there are three important statements related to the relationship between online learning evaluation and learning outcomes and student perceptions are obtained as shown in Figure 1.

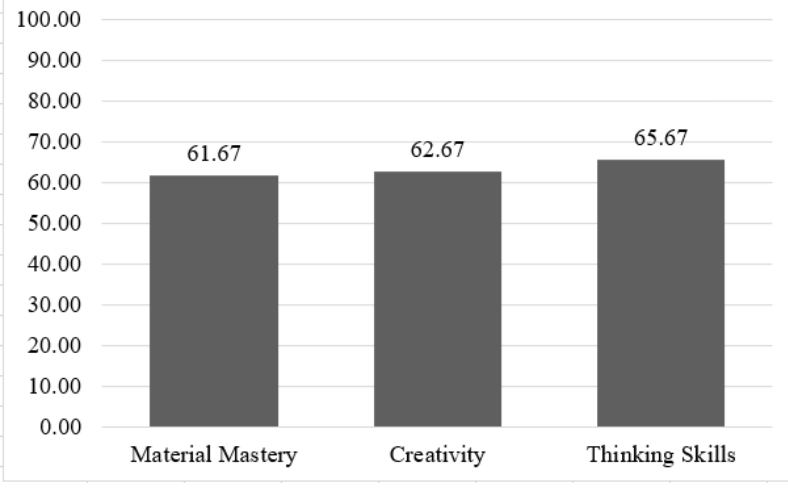

Fig. 1. Students' Responses Regarding the Relationship between Online Learning Evaluation and Learning Outcomes

Figure 1 shows the level of students' perceptions regarding the statements given. Overall, the data shows that students disagree with statements that explain "online evaluations can measure students 'mastery of the material being taught, online learning evaluations can increase student creativity, and online learning evaluations can train students' thinking skills". A contradictory statement was conveyed by Setemen [3] which stated that online learning evaluation was well received by students and overall students stated that they strongly agreed with online learning evaluation.

Students give a statement that they do not agree with the statements submitted in the questionnaire. They expressed this for several basic reasons, such as statements related to online evaluation which could measure student mastery, they stated that the questions given were not comparable with the material that was explained during the lecture process. This statement arises because students think that the material given is small, but at the time of evaluation, questions related to material that have not been previously explained appear. This reason is the basis for students to consider online learning evaluations as currently ineffective in measuring student mastery of material.

In the second statement regarding online learning evaluation being able to increase creativity and thinking skills, they assumed that online evaluation was less capable of increasing creativity and thinking skills because it was limited by time and they thought that face-to-face evaluation was better than online. This is because with face-to-face students can more freely explore their creativity because it is not too limited by time and easier in confirming everything they still doubt. This is not in line with the statement of Setemen [3] which states that online learning evaluation does not require a lot of time and money to produce instruments, for scoring and processing scores, to provide feedback to students, and this type of evaluation does not cause anxiety in test taker. Kicken [7] also states that online evaluation can improve students' ability to formulate learning needs, choose meaningful learning activities, and complete learning tasks. Sutopo [8] adds that evaluation of learning that does not use face to face does not require the presence of students and examination supervisors at the specified place and time.

After the evaluation data is obtained, data collection is carried out on student learning outcomes who have provided statements on the online learning evaluation questionnaire. The value of student learning outcomes is obtained from the results of the final semester examinations which are carried 
out online. After the student learning outcomes data are obtained, the online learning evaluation data and learning outcomes are analyzed first with SPSS to see whether the two data are normal or not. Normality test data from online learning evaluations and learning outcomes are shown in Table II

TABLE II. DATA NORMALITY TEST

\begin{tabular}{|c|c|c|c|}
\hline \multirow{2}{*}{} & \multicolumn{3}{|c|}{ Kolmogorov-Smirnova } \\
\cline { 2 - 4 } & Statistic & df & Sig. \\
\hline Online Learning Evaluation & 0.159 & 75 & 0.000 \\
\hline Learning outcomes & 0.070 & 75 & $0.200^{*}$ \\
\hline
\end{tabular}

After carrying out the data normality test as shown in Table II, it was found that the significant value of the online learning evaluation was 0,000 and student learning outcomes with a significant value of 0.200 . This states that the online learning evaluation data is not normally distributed because the significant value is less than 0.05 , while the learning outcome data is in the normally distributed category because the significant value is more than 0.05 . The normality test is carried out as a prerequisite test before the correlation test is carried out. After the normality test on both data was carried out, then a correlation test was carried out to determine the level of the relationship between online learning evaluations and student learning outcomes. The results of the correlation test for the two data are presented in Table III.

TABLE III. CORRELATION OF ONLINE LEARNING EVALUATION WITH STUDENTS' LEARNING OUTCOMES

\begin{tabular}{|c|c|c|c|c|}
\hline & & & $\begin{array}{c}\text { Online } \\
\text { Learning } \\
\text { Evaluation } \\
\end{array}$ & $\begin{array}{l}\text { Learning } \\
\text { outcomes }\end{array}$ \\
\hline \multirow[t]{6}{*}{$\begin{array}{l}\text { Spearman's } \\
\text { rho }\end{array}$} & \multirow{3}{*}{$\begin{array}{l}\text { Online } \\
\text { Learning } \\
\text { Evaluation }\end{array}$} & $\begin{array}{l}\text { Correlation } \\
\text { Coefficient }\end{array}$ & 1.000 & -.007 \\
\hline & & $\begin{array}{l}\text { Sig. (2- } \\
\text { tailed) }\end{array}$ & . & .952 \\
\hline & & $\mathrm{N}$ & 75 & 75 \\
\hline & \multirow[t]{3}{*}{$\begin{array}{l}\text { Learning } \\
\text { outcomes }\end{array}$} & $\begin{array}{l}\text { Correlation } \\
\text { Coefficient }\end{array}$ & -.007 & 1.000 \\
\hline & & $\begin{array}{l}\text { Sig. (2- } \\
\text { tailed) }\end{array}$ & .952 & . \\
\hline & & $\mathrm{N}$ & 75 & 75 \\
\hline
\end{tabular}

Based on the correlation test that has been done, the correlation data obtained between online learning evaluations and student learning outcomes. From Table III, it is known that the correlation coefficient value is 0.007 (negative) and the significance value is 0.952 . These data indicate that there is no positive and insignificant relationship between online learning evaluation and student learning outcomes. The data also shows that the relationship or correlation between online learning evaluation and learning outcomes seen from the correlation coefficient value of -0.007 is in the very weak relationship category.

The results of this correlation test are in line with the statements conveyed by students who expressed disagreement with online learning evaluations which can improve learning outcomes. This shows that to see the relationship between online learning evaluation and strong learning outcomes, other variables are needed as moderating variables of the study. Rolisca \& Achadiyah [9] state that the potential advantages of online learning evaluation are direct score reporting, decreased administrative costs on school district personnel, increased safety of testing materials, and more flexible exam scheduling. In many countries, policy makers say they are happy with the potential for efficient measurement of student abilities through the online exam model.

The absence of a relationship between online learning evaluations and learning outcomes here is in terms of whether online learning evaluations can improve learning outcomes. However, from several other aspects, online learning evaluation and learning outcomes have a strong enough relationship, such as students feeling interested in online learning evaluations, feeling motivated, not lazing around, serious in working on questions, and not feeling bored and bored. This has an indirect impact on student learning outcomes.

\section{CONCLUSION}

Based on the results of the research that has been done, information was obtained that online learning evaluations during the Covid-19 pandemic has weak correlation with the learning outcomes obtained by students of Universitas Samawa. Thus, it can be concluded that the online learning evaluation variable requires supporting variables to determine students' learning outcomes. The authors suggest that further researchers would use more than two variables to review the correlation which is the aim of the study.

\section{ACKNOWLEDGMENT}

The research team would like to thank the National Research and Innovation Agency (RISTEK-BRIN) for financing this research activity. The author also thanks the Institute of Research and Community Service (LPPM) Universitas Samawa for facilitating this activity so that it can be carried out properly as well as the lecturers and students in Universitas Samawa who are willing to become respondents in this research activity.

\section{REFERENCES}

[1] R. E. Bennett, "Formative assessment: A critical review," Assessment in Education: Principles, Policy \& Practice, vol. 18, no. 1, pp. 5-25, 2011.

[2] W. Kicken, "The Effects of Portofolio-based Advice on The Development of Self-Directed Learning Skills in Secondary Vocational Educations," Education Tech Research Dev, vol. 57, pp. 439-460, 2009.

[3] M. Nicola, Z. Alsafi, C. Sohrabi, A. Kerwan, A. Al-Jabir, C. Iosifidis, and R. Agha, "The socio-economic implications of the coronavirus and COVID-19 pandemic: a review," International Journal of Surgery, 2020

[4] J. W. Pellegrino, N. Chudowsky, R. Glaser, Knowing what students know: The science and design of educational assessment. Washington, DC: National Academies Press, 2001.

[5] A. Purwanto, R. Pramono, M. Asbari, C. C. Hyun, L. M. Wijayanti, and R. S. Putri, "Studi Eksploratif Dampak Pandemi COVID-19 Terhadap Proses Pembelajaran Online di Sekolah Dasar," EduPsyCouns: Journal of Education, Psychology and Counseling, vol. 2, no.1, pp. 1-12, 2020.

[6] R. U. C. Rolisca and B. N. Achadiyah, "Pengembangan Media Evaluasi Pembelajaran Dalam Bentuk Online Berbasis E-Learning Menggunakan Software Wondershare Quiz Creator Dalam Mata Pelajaran Akuntansi SMA Brawijaya Smart School (BSS),”. Jurnal Pendidikan Akuntansi Indonesia, vol. 12, no. 2, 2014. 
[7] K. Setemen, "Pengembangan evaluasi pembelajaran online. Jurnal Pendidikan dan pengajaran," vol. 43, no. 3, 2010.

[8] H. Sutopo, "Pengembangan Evaluasi Pembelajaran Berbasis Mulimedia Dengan Flash, Php, Dan Mysql,” Jurnal Informatika, vol. 10, no. 2, pp. 79-85, 2009.

[9] N. Z. N. Zahara, "Evaluasi Pembelajaran Online Berbasis Web Sebagai Alat Ukur Hasil Belajar Siswa Pada Materi Dunia Tumbuhan Kelas X Man Model Banda Aceh," Prosiding Biotik, vol. 2, no.1, 2018. 